Удк 632.913.1:632.51

DOI https://doi.org/10.32848/agrar.innov.2021.8.9

\title{
АНАЛІЗ ФІТОСАНІТАРНОГО СТАНУ ХЕРСОНСЬКОЇ ОБЛАСТІ ЗА ПОШИРЕННЯМ КАРАНТИННИХ БУР'ЯНІВ
}

\author{
МАКУХА О.В. - кандидат сільськогосподарських наук, доцент \\ https://orcid.org/0000-0002-4509-7331 \\ Херсонський державний аграрно-економічний університет
}

Постановка проблеми. Інвазійний бур'ян можна визначити як рослину, переміщену зі свого ареалу до іншого, віддаленого місця, що має негативний вплив на види, які перебувають на цій території, на природні або агроекосистеми та характеризується здатністю швидко поширюватись у просторі та колонізації, що дозволяє зайняти нові ніші [1; 2]. Карантинні види рослин представляють небезпеку для оточуючого середовища та економіки на місцевому і глобальному рівнях [2; 3], негативно впливають на стабільність і біорізноманіття екосистем, сільськогосподарське виробництво, здоров'я людей $[4 ; 5]$.

Порушення екологічних систем, спричинені біологічною інвазією, були визнані зростаючою загрозою глобальній стійкості [6]. Чужорідні види рослин вважаються однією з основних рушійних сил втрати біорізноманіття [2; 7]. Інвазійні рослини здатні витісняти місцеві види, спричиняти зміни структури та функцій екосистем, стану природних та агроландшафтів, завдавати економічних збитків [8; 9]. На відміну від хімічних забруднювачів, які руйнуються з часом і дозволяють екосистемі відновлюватися, інвазійні організми розмножуються та поширюються, що призводить до їх укорінення. Наслідками біологічної інвазії є витіснення або заміщення місцевих рослин, порушення кругообігу речовин, зміни сукцесії рослин [2]. Розвитку карантинних бур'янів сприяють зміни клімату, що супроводжуються підвищенням температури повітря [10; 11].

Міжурядова науково-політична платсрорма Організації Об'єднаних Націй із питань біологічного різноманіття та екосистемних послуг розробила прогноз, згідно з яким близько однієї п'ятої поверхні Землі, включаючи світові гарячі точки біорізноманіття, знаходиться під загрозою біологічного вторгнення [12]. Країни з високим рівнем доходу зафіксували у 30 разів більшу кількість чужорідних видів рослин порівняно із країнами з низьким рівнем доходу [13]. Загроза вторгнення карантинних видів до країн Європейського Союзу, Австралії та Північної Америки є вищою, ніж на Африканському континенті і в Азіатсько-Тихоокеанському регіоні [12; 13], що можна пояснити зростанням торговельної і транспортної діяльності у країнах із високим доходом на душу населення.

Темпи поширення й укорінення інвазійних бур'янів у світі зростають через процеси глобалізації [14]. Проблема фітосанітарного контролю карантинних бур'янів $€$ актуальною для України з огляду на перехід аграрного сектору до якісно нової стадії, зумовленої процесами глобалізації та євроінтеграції, стрімким виходом на світовий продовольчий ринок [15].
Аналіз останніх досліджень і публікацій. Поширення інвазійних видів у природі не має географрічних меж [2; 11]. У карантинних бур'янів сформовано унікальні еволюційні механізми, що сприяють змінам їх онтогенезу й морфології, забезпечуючи значну пластичність та адаптивні властивості [16]. Інвазійні рослини характеризуються зазвичай спільними біологічними ознаками щодо високого репродуктивного потенціалу й толерантності до стресових фракторів. До таких ознак належать: невимогливість рослин у період проростання насіння; швидкий ріст на початкових етапах розвитку і перехід до статевої зрілості; раннє достигання та формування життєздатного насіння з високими показниками схожості; розмноження вегетативним і статевим способами; різноманітні механізми поширення, зокрема кореневими паростками або кореневищами; значна конкурентоспроможність порівняно 3 місцевими видами; здатність адаптуватися до широкого спектру екологічних умов, витримуючи несприятливий вплив фракторів навколишнього середовища [2].

Занесенню чужорідних видів сприяють їхня інтродукція, порушення і деградація середовища існування, відсутність природних ворогів на новій території [2]. На інвазію рослин та їхнє подальше існування в новій зоні впливають кліматичні, геологічні, ґрунтові умови, наявність доступної вологи та інші фрактори [11]. Зміни температури, режимів зволоження та екстремальні кліматичні умови діють на всі рослини, але карантинні види порівняно із місцевими зазвичай краще пристосовані до їх впливу [16]. Інвазійні рослини здатні зменшити кількість світла, води, поживних речовин і простору, доступного для місцевих видів, змінити водно-фрізичні та хімічні властивості ґрунту, зокрема вбирну здатність, стійкість до ерозії тощо [17; 18].

Мета. Мета дослідження - аналіз фрітосанітарного стану Херсонської області за поширенням карантинних бур'янів, зазначених у списку А-2 «Перелік регульованих шкідливих організмів», визначення тенденцій зміни засмічених площ за окремими видами.

Матеріали та методика досліджень. Аналіз фітосанітарного стану Херсонської області за видами обмежено поширених бур'янів виконували з 01.01.2016 до 01.01.2021 рр. на основі «Огляду поширення карантинних організмів в Україні» Державної служби України з питань безпечності харчових продуктів та захисту споживачів за відповідний період [19].

До обмежено поширених в Україні карантинних бур'янів, зазначених у списку А-2 «Перелік регульованих шкідливих організмів», належать такі види: гірчак повзучий (степовий) Acroptilon repens L., амброзія поли- 
нолиста Ambrosia artemisiifolia L., ценхрус довгоголковий Cenchrus longispinus Fernald, повитиці Cuscuta spp. (польова, Лемана, одностовпчикова, хмельовидна), сорго алепське (гумай) Sorghum halepense (L.) Pers., паслін колючий Solanum rostratum Dunal. Із цих видів на території Херсонської області зареєстровані гірчак повзучий, амброзія полинолиста, ценхрус довгоголковий, повитиця польова та паслін колючий [19; 20].

Завдання дослідження включали аналіз засмічених у Херсонській області площ за видами обмежено поширених карантинних бур'янів, зокрема за категоріями (присадибні ділянки, господарства, інші землі), кількістю зон, в яких введено карантинний режим, а також визначення тенденцій зміни та варіювання площі поширення кожного виду в області за роками, її питомої ваги до загальної площі в Україні. Під час досліджень використовували загальнонаукові методи (аналіз, синтез, індукція, дедукція, аналогія, узагальнення), застосовували варіаційний метод математичної статистики [21; 22].

Результати досліджень. Забур'янена амброзією полинолистою площа станом на перше січня 2016-2021 рр. становила в області 8,8-9,4 \% від площі в Україні. Цей показник зменшився у вищезазначений період від 277011,3 до 275350,6 га, або на 0,6\% (рис. 1). Ступінь зміни площі амброзії полинолистої за роками був незначним, що підтверджується величиною коефіцієнта варіації на рівні $0,2 \%$. Кількість карантинних одиниць залишалася стабільною і становила 293. Поширення амброзії на присадибних ділянках зафріксовано на площі 1583,0 га, яка у вищезазначений період залишалася незмінною. Основну частину засмічених бур'яном площ (265073,5-266548,6 га) зосереджено в господарствах усіх форм власності. На інших землях амброзія займала площу 8694,1-8879,7 га.

Площа, засмічена гірчаком повзучим на 01.01.2016-01.01.2021 рр., становила у Херсонській області 89,1-91,5\% від площі, зайнятої цим карантинним видом в Україні. Аналіз поширення гірчака повзучого в області свідчить про тенденцію зменшення в зазначений період забур'яненої площі від 203162,4 до 199808,6 га або на 1,7 \%, та стабілізацію цього показника впродовж останніх трьох років (рис. 2). Виявлена закономірність $€$ аналогічною тенденції зменшення площі, забур'яненої амброзією полинолистою. Варіювання за роками площі, зайнятої гірчаком повзучим, виявилося незначним, адже величина коефіцієнта варіації знаходилася на рівні 0,7\%. Карантинний режим щодо гірчака повзучого запроваджено у 133 зонах. За категоріями суб'єктів господарювання цей вид найбільшу площу (199255,2-202609,0 га) займав у господарствах різних форм власності. На присадибних ділянках та інших землях засмічена площа була стабільною і становила 30,4 та 523,0 га відповідно.

У Херсонській області зосереджено основну частину площ ценхруса довгоголкового - 99,8 \% від площі цього виду в Україні. Станом на 01.01.2016 р. карантинний бур'ян зареєстровано на площі 21606,5 га, з 01.01.2017 р. площа його поширення зменшилася до 20052,2 га або на 7,2 \%, та залишалася стабільною протягом останніх п'яти років. Величина коефіцієнта варіації на рівні 3,1\% указує на незначне коливання засміченої площі за роками. Кількість карантинних зон в області внаслідок поширення ценхруса довгоголкового дорівнювала 52. У господарствах цей вид займав площу 19616,6-21170,9 га; на присадибних ділянках та інших землях площа його поширення була значно меншою 2,1 та 433,5 га відповідно.

Питома вага площі поширення повитиці польової у Херсонській області дорівнювала 23,5-25,6\% у структурі площ, засмічених цим видом в Україні. У період з 01.01.2016 р. до 01.01.2021 р. забур'янена площа знизилася від 6052,7 до 5242,0 га, або на 13,4 \%. Ступінь

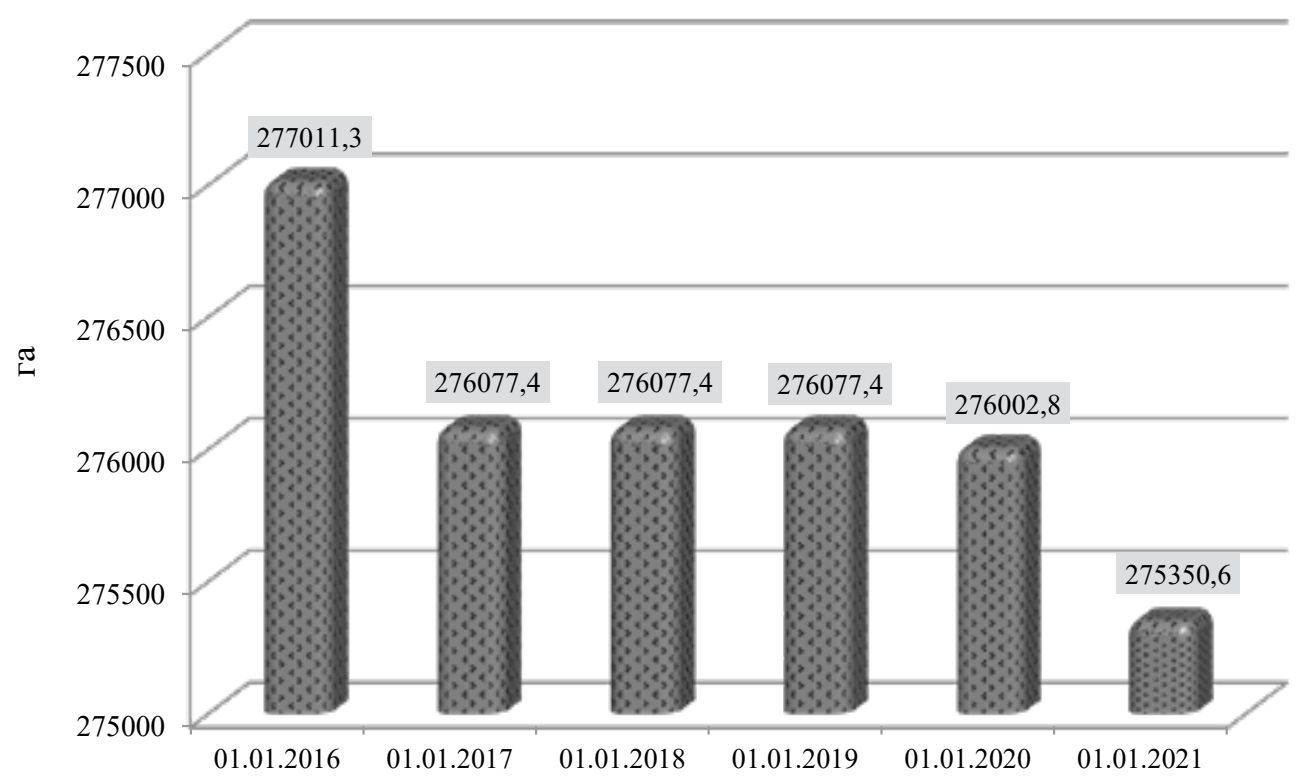

Рис. 1. Площа, забур'янена амброзією полинолистою в Херсонській області, га 


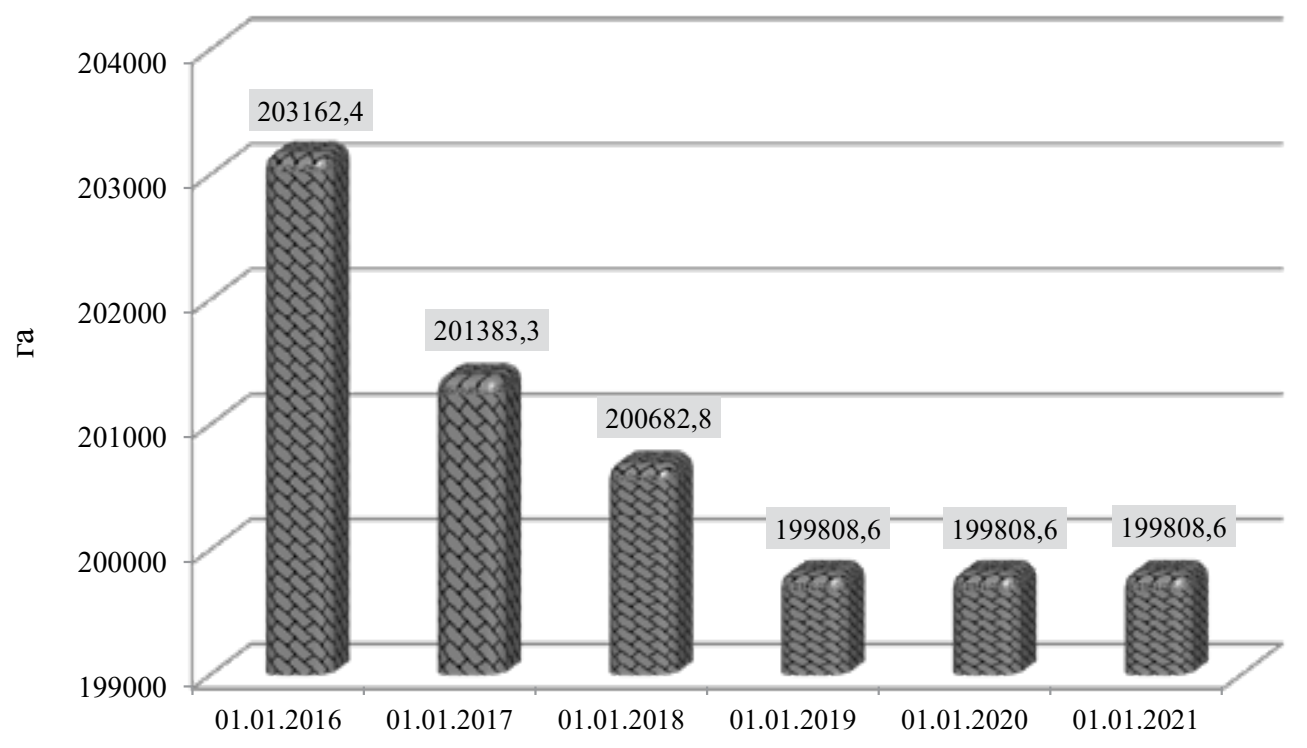

Puc. 2. Площа, забур'янена гірчаком повзучим у Херсонській області, га

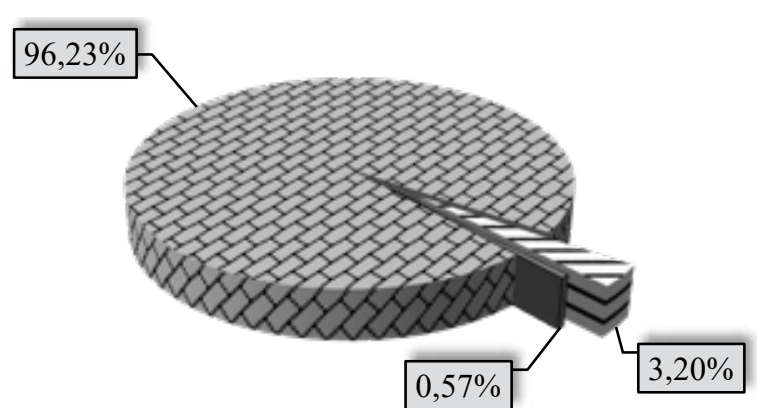

口присадибні ділянки ८ господарства $=$ інші землі

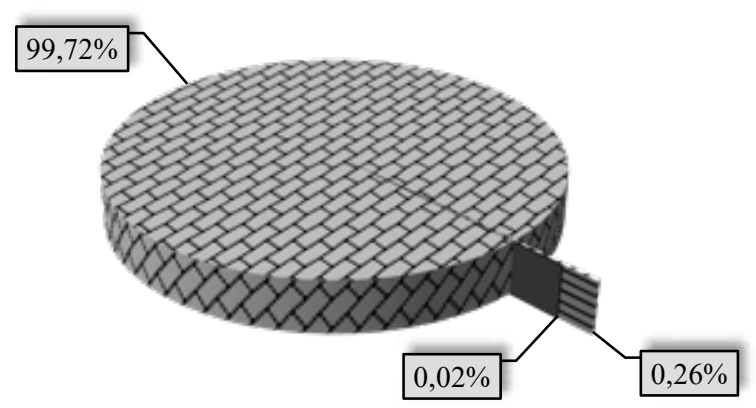

口присадибні ділянки $\triangle$ господарства - інші землі

а 6

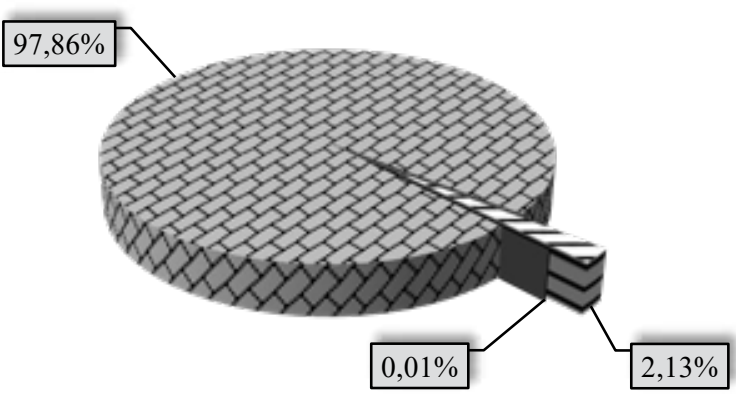

口присадибні ділянки 邓 господарства - інші землі

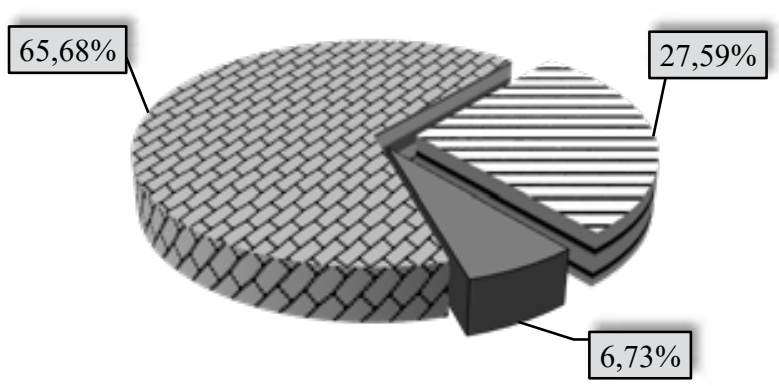

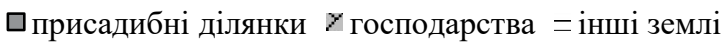

B $\Gamma$

a - амброзія полинолиста; б - гірчак повзучий;

в - ценхрус довгоголковий; г - повитиця польова

Puc. 3. Структура площ, забур'янених у Херсонській області обмежено поширеними видами бур'янів, у розрізі суб'єктів господарювання (\%) 
варіювання площі повитиці польової за роками був незначним, коефіцієнт варіації знаходився на рівні 5,3\%. Карантинний режим запроваджено у 292 зонах, їхня кількість станом на перше січня 2021 р. зменшилася до 290 одиниць. У структурі засмічених повитицею польовою площ присадибні ділянки займали 325,4-581,4 га, господарства - 3491,8-3802,5 га, інші землі - 1424,8-1668,8 га. Аналіз площі поширення карантинного об'єкта вказує на зниження цього показника за всіма категоріями суб'єктів господарювання протягом досліджуваного періоду.

В Україні паслін колючий виявлено тільки в Херсонській області на площі 134,0 га в одній карантинній зоні.

Аналіз структури площ, засмічених у Херсонській області обмежено поширеними видами бур'янів, свідчить, що основну їх частину зареєстровано на території господарств усіх форм власності. Питома вага зазначеної категорії суб'єктів господарювання становила 96,23 \% для амброзії полинолистої, 99,72 \% для гірчака повзучого, 97,86 \% для ценхруса довгоголкового та 65,68 \% для повитиці польової порівняно із загальною площею, засміченою кожним видом бур'яну. Площа поширення вищезазначених видів на присадибних ділянках становила у відносному виразі до їхньої загальної площі в області 0,57; 0,02; 0,01 та $6,73 \%$, на інших землях - 3,20; 0,26; 2,13 та 27,59 \%, відповідно (рис. 3). Паслін колючий був поширений тільки в господарствах.

Висновки. Серед обмежено поширених в Україн карантинних бур'янів списку А-2 «Перелік регульованих шкідливих організмів» у Херсонській області зареєстровані гірчак повзучий (Acroptilon repens L.), амброзія полинолиста (Ambrosia artemisiifolia L.), ценхрус довгоголовий, (Cenchrus longispinus Fernald), повитиця польова (Cuscuta campestris Junk.) та паслін колючий (Solanum rostratum Dunal.). У період із 01.01.2016 до 01.01.2021 рр. в області спостерігалася тенденція зменшення площі поширення зазначених видів бур'янів, окрім пасльону колючого, площа якого залишалася незмінною. Ступінь варіювання площ, засмічених гірчаком повзучим, амброзією полинолистою, ценхрусом довгоголковим і повитицею польовою, у вищезазначений період був незначним, що підтверджено результатами статистичного аналізу. Основну частину забур'янених площ зосереджено в господарствах усіх форм власності.

\section{СПИСОК ВИКОРИСТАНОЇ ЛІТЕРАТУРИ:}

1. Clements D. R. Invasive weed species and their effects. Integrated Weed Management for Sustainable Agriculture / edited by R. Zimdahl. Cambridge, UK: Burleigh Dodds Science Publishing, 2017. P. 65-88.

2. Bhowmik P. C. Invasive weeds and climate change: past, present and future. Journal of Crop and Weed. 2014. 10 (2). P. 345-349.

3. Bartz R., Kowarik I. Assessing the environmental impacts of invasive alien plants: a review of assessment approaches. NeoBiota. 2019. Vol.43. P. 69-99.

4. Invasive weed species' threats to global biodiversity: future scenarios of changes in the number of invasive species in a changing climate / Shabani F. et al.
Ecological Indicators. 2020. Vol. 116, article 106436. DOI: $10.1016 /$ j.ecolind.2020.106436.

5. Jones B. A. Tree shade, temperature, and human health: evidence from invasive species-induced deforestation. Ecological Economics. 2019. Vol. 156. P. 12-23.

6. Rai P. K., Singh J. S. Invasive alien plant species: their impact on environment, ecosystem services and human health. Ecological Indicators. 2020. Vol.111, article 106020. P. 1-20. DOI: 10.1016/j.ecolind.2019.106020.

7. Bellard C., Cassey P., Blackburn T. M. Alien species as a driver of recent extinctions. Biology Letters. 2016. No12, article 20150623. P. 1-5. DOI: 10.1098/rsbl.2015.0623.

8. Future distribution of invasive weed species across the major road network in the state of Montana, USA / Adhikari A., Rew L. J., Mainali K. P., Adhikari S., Maxwell B. D. Regional Environmental Change. 2020. No20 (60). P. 1-14.

9. The invasion paradox: reconciling pattern and process in species invasions / Fridley J. D. et al. Ecology. 2007. Vol.88. P. 3-17. DOI: 10.1890/0012-9658(2007)88.

10. The Anthropocene biosphere / Williams M. Zalasiewicz J., Haff P. C., Barnosky A. D., Ellis E. C. The Anthropocene Review. 2015. No2. P. 196-219. DOI: 10.1177/2053019615591020.

11. Bradley B. A., Oppenheimer M., Wilcove P. S. Climate change increases risk of plant invasion in the Eastern United States. Biological Invasions. 2010. No12. P. 1855-1872.

12. Summary for policymakers of the global assessment report on biodiversity and ecosystem services of the Intergovernmental Science-Policy Platform on Biodiversity and Ecosystem Services / Diaz S. et al. Global Assessment Report on Biodiversity and Ecosystem Services. Bonn, Germany: IPBES secretariat, 2019.

13. Seebens H. Global rise in emerging alien species results from increased accessibility of new source pools. Proceedings of the National Academy of Sciences of the USA. 2018. Vol.115 (10). P. 2264-2273.

14. Something in the way you move: dispersal pathways affect invasion success / Wilson J. R. U., Dormontt E. E., Prentis P. J., Lowe A. J., Richardson D. M. Trends in Ecology \& Evolution. 2009. Vol.24. P. 136-144. DOI: 10.1016/j. tree.2008.10.007.

15. Кирилов Ю. Є. Розвиток аграрного сектору економіки в умовах глобалізації. Економіка АПК. 2016. № 5. C. 23-29.

16. Clements D. R., Jones V. L. Rapid evolution of invasive weeds under climate change: present evidence and future research needs. Frontiers in Agronomy. 2021. P. 1-16. DOI: 10.3389/fagro.2021.664034.

17. Skurski T. C., Rew L. J., Maxwell B. D. Mechanisms underlying non-indigenous plant impacts: a review of recent experimental research. Invasive Plant Science and Management. 2014. No7. P. 432-444. DOI: 10.1614/IPSM-D-13-00099.1.

18. Van Kleunen M. et al. Global exchange and accumulation of non-native plants. Nature. 2015. Vol. 525. P. 100-103. DOI: $10.1038 /$ nature 14910 .

19. Огляд поширення карантинних організмів в Україні. Державна служба України з питань безпечності харчових продуктів та захисту споживачів. URL: https:// afly.co/3np6 (дата звернення: 27.06.2021).

20. Перелік регульованих шкідливих організмів / Міністерство аграрної політики та продоволь- 
ства України. URL: https://zakon.rada.gov.ua/laws/ show/ z0879-19\#Text (дата звернення: 19.06.2021).

21. Єщенко В. О., Копитко П. Г., Костогриз П. В., Опришко В. П. Основи наукових досліджень в агрономії. Вінниця: Едельвейс і К., 2014. С. 257-312.

22. Ушкаренко В. О., Нікішенко В. Л., Голобородько С. П., Коковіхін С. В. Дисперсійний і кореляційний аналіз результатів польових дослідів: навчальний посібник. Херсон : Айлант, 2009. 372 с.

\section{REFERENCES:}

1. Clements, D. R., edited by Zimdahl, R. (2017). Invasive weed species and their effects. Integrated Weed Management for Sustainable Agriculture. Burleigh Dodds Science Publishing, Cambridge, UK. [in English].

2. Bhowmik, P. C. (2014). Invasive weeds and climate change: past, present and future. Journal of Crop and Weed, 10 (2), 345-349 [in English].

3. Bartz, R., Kowarik, I. (2019). Assessing the environmental impacts of invasive alien plants: a review of assessment approaches. NeoBiota, 43, 69-99 [in English].

4. Shabani, F. et al. (2020). Invasive weed species' threats to global biodiversity: future scenarios of changes in the number of invasive species in a changing climate. Ecological Indicators, 116, article 106436. https:// doi.org/10.1016/j.ecolind.2020. 106436 [in English].

5. Jones, B. A. (2019). Tree shade, temperature, and human health: evidence from invasive species-induced deforestation. Ecological Economics, 156, 12-23 [in English].

6. Rai, P. K., Singh, J. S. (2020). Invasive alien plant species: their impact on environment, ecosystem services and human health. Ecological Indicators, 111, article 106020, 1-20. https://doi.org/10.1016/j. ecolind.2019.106020 [in English].

7. Bellard, C., Cassey, P., Blackburn, T. M. (2016). Alien species as a driver of recent extinctions. Biology Letters, 12, article 20150623, 1-5. https://doi.org/10.1098/ rsbl.2015.0623 [in English].

8. Adhikari, A., Rew, L. J., Mainali, K. P., Adhikari, S., Maxwell, B. D. (2020). Future distribution of invasive weed species across the major road network in the state of Montana, USA. Regional Environmental Change, 20 (60), 1-14 [in English].

9. Fridley, J. D. et al. (2007). The invasion paradox: reconciling pattern and process in species invasions. Ecology, 88, 3-17. https://doi.org/10.1890/0012-9658(2007)88 [in English].

10. Williams, M., Zalasiewicz, J., Haff, P. C., Barnosky, A. D., Ellis, E. C. (2015). The Anthropocene biosphere. The Anthropocene Review, 2, 196-219. https://doi.org/ 10.1177/2053019615591020 [in English].

11. Bradley, B. A., Oppenheimer, M., Wilcove, P. S. (2010). Climate change increases risk of plant invasion in the Eastern United States. Biological Invasions, 12, 1855-1872 [in English].

12. Diaz, S. et al. (2019). Summary for policymakers of the global assessment report on biodiversity and ecosystem services of the Intergovernmental SciencePolicy Platform on Biodiversity and Ecosystem Services. Global Assessment Report on Biodiversity and Ecosystem Services. IPBES secretariat, Bonn, Germany [in English].
13. Seebens, H. (2018). Global rise in emerging alien species results from increased accessibility of new source pools. Proceedings of the National Academy of Sciences of the USA, 115 (10), 2264-2273 [in English].

14. Wilson, J. R. U., Dormontt, E. E., Prentis, P. J., Lowe, A. J., Richardson, D. M. (2009). Something in the way you move: dispersal pathways affect invasion success. Trends in Ecology \& Evolution, 24, 136-144. https://doi.org/10.1016/j.tree.2008. 10.007 [in English].

15. Kyrylov, Y. Y. (2016). Rozvytok ahrarnoho sektoru ekonomiky $v$ umovakh hlobalizatsii [Development of the agricultural sector of the economy in the context of globalization]. Ekonomika APK - Economics of agro-industrial complex, 5, 23-29 [in Ukrainian].

16. Clements, D. R., Jones, V. L. (2021). Rapid evolution of invasive weeds under climate change: present evidence and future research needs. Frontiers in Agronomy, 1-16. https://doi.org/10.3389/fagro.2021.664034 [in English].

17. Skurski, T. C., Rew, L. J., Maxwell, B. D. (2014). Mechanisms underlying non-indigenous plant impacts: a review of recent experimental research. Invasive Plant Science and Management, 7, 432-444. https:// doi.org/10.1614/IPSM-D-13-00099.1 [in English].

18. Van Kleunen, M. et al. (2015). Global exchange and accumulation of non-native plants. Nature, 525, 100-103. https://doi.org/10.1038/nature14910 [in English].

19. Ohliad poshyrennia karantynnykh orhanizmiv v Ukraini [Review of the spread of quarantine organisms in Ukraine]. Derzhavna sluzhba Ukrainy z pytan bezpechnosti kharchovykh produktiv ta zakhystu spozhyvachivState Service of Ukraine on Food Safety and Consumer Protection. URL: https://afly.co/3np6 [in Ukrainian].

20. Perelik rehulovanykh shkidlyvykh orhanizmiv [List of regulated pests]. Ministerstvo ahrarnoi polityky ta prodovolstva Ukrainy - Ministry of Agrarian Policy and Food of Ukraine. URL: https://zakon.rada.gov.ua/laws/ show/ z0879-19\#Text [in Ukrainian].

21. Yeshchenko, V. O., Kopytko, P. H., Kostohryz, P. V., Opryshko, V. P. (2014). Osnovy naukovykh doslidzhen $\checkmark$ ahronomii [Fundamentals of scientific research in agronomy]. Edelveis i K, Vinnytsia [in Ukrainian].

22. Ushkarenko, V. O., Nikishenko, V. L., Holoborodko, S. P., Kokovikhin, S. V. (2009). Dyspersiinyi i koreliatsiinyi analiz rezultativ poliovykh doslidiv: navchalnyi posibnyk [Analysis of variance and correlation of the results of field experiments: a textbook]. Ailant, Kherson [in Ukrainian].

Макуха О.В. Аналіз фрітосанітарного стану Херсонської області за поширенням карантинних бур'янів

Мета дослідження - аналіз фітосанітарного стану Херсонської області за поширенням карантинних бур'янів, зазначених у списку А-2 «Перелік регульованих шкідливих організмів» і визначення тенденцій зміни засмічених площ за окремими видами. Методи. Аналіз проведено у період з 01.01.2016 до 01.01.2021 рр. на основі даних Державної служби України з питань безпечності харчових продуктів та захисту споживачів за такими видами обмежено поширених карантинних бур'янів: гірчак повзучий Acroptilon repens L., амброзія полинолиста Ambrosia artemisiifolia L., ценхрус довгоголковий Cenchrus longispinus Fernald, повитиця польова Cuscuta campestris Junk. та паслін колючий Solanum rostratum 
Dunal. Під час дослідження використовували загальнонаукові методи, застосовували варіаційний метод математичної статистики. Результати. Забур'янена амброзією полинолистою площа станом на перше січня 2016-2021 рр. зменшилася від 277011,3 до 275350,6 га. Площа, засмічена гірчаком повзучим, скоротилася від 203162,4 до 199808,6 га і залишалася стабільною протягом останніх трьох років. Станом на 01.01.2016 р. ценхрус довгоголковий зареєстровано на площі 21606,5 га, з 01.01.2017 р. площа його поширення зменшилася до 20052,2 га та була незмінною останні п'ять років. Площа, забур'янена повитицею польовою, скоротилась у досліджуваний період від 6052,7 до 5242,0 га. Паслін колючий на території країни було виявлено тільки в Херсонській області на площі 134,0 га. Аналіз структури площ, засмічених обмежено поширеними видами бур'янів, свідчить про те, що основну їхню частину в Херсонській області зареєстровано в господарствах усіх форм власності. Паслін колючий був поширений тільки в господарствах. Висновки. У період із 01.01.2016 до 01.01.2021 рр. у Херсонській області спостерігалася тенденція зменшення площ, засмічених гірчаком повзучим, амброзією полинолистою, ценхрусом довгоголковим та повитицею польовою. Ступінь варіювання площ поширення зазначених видів бур'янів за роками був незначним, що підтверджується результатами статистичного аналізу Незмінною в Херсонській області залишалася площа пасльону колючого.

Ключові слова: обмежено поширений карантинний бур'ян, забур'янена площа, карантинна зона, гірчак повзучий, амброзія полинолиста, ценхрус довгоголковий, повитиця польова, паслін колючий.

Makukha O.V. Analysis of phytosanitary status of Kherson region by distribution of quarantine weeds

The purpose of the research was to analyze the phytosanitary status of the Kherson region for the distribution of quarantine weeds included in the «List of regulated pests» (A-2), to determine trends of changes in weedy areas by individual species. Methods. The analysis was performed from 01.01.2016 to 01.01 .2021 on the basis of data of the State Service of Ukraine on Food Safety and Consumer Protection for the following species of limited spread quarantine weeds: Russian knapweed Acroptilon repens L., common ragweed Ambrosia artemisiifolia L., long-spine sandbur Cenchrus longispinus Fernald, field dodder Cuscuta campestris Junk., and Buffalobur Solanum rostratum Dunal. During the research, the general scientific methods and the variation method of mathematical statistics were used. Results. As of January 1, 2016-2021, the area weeded with common ragweed decreased from 277011.3 to 275350.6 ha. The area infested with Russian knapweed reduced from 203162.4 to 199808.6 ha and remained stable for the last three years. As of 01.01.2016, longspine sandbur was registered on the area of 21606.5 ha, since 01.01.2017 the area of its distribution decreased to 20052.2 ha and was unchanged for the last five years. The area of the field dodder reduced during the study period from 6052.7 to 5242.0 ha. Buffalobur in the country was found only in the Kherson region on the area of 134.0 ha. Analysis of the structure of areas infested with limited spread species of weeds testifies that most of them in the Kherson region are registered in the agricultural enterprises and farms of all forms of ownership. Buffalobur was detected only in the households. Findings. In the Kherson region, from 01.01.2016 to 01.01.2021 there was a tendency to reduce the areas weeded with Russian knapweed Acroptilon repens L., common ragweed Ambrosia artemisiifolia L., long-spine sandbur Cenchrus longispinus Fernald, and field dodder Cuscuta campestris Junk. The degree of variation of the distribution areas of these weed species over the years was insignificant, which is confirmed by the results of statistical analysis. In the Kherson region, the area of Buffalobur (Solanum rostratum Dunal.) remained unchanged.

Key words: limited spread quarantine weed, weedy area, quarantine zone, Russian knapweed, common ragweed, long-spine sandbur, field dodder, Buffalobur.v 